\title{
Problems and Potentials of Rural Growth Center: A Case Study of Rammohan Bazar at Barura Upazila in Cumilla District, Bangladesh
}

By Md. Ziaul Haq

Abstract- Rural growth center can play a vital role in developing the economic condition of the rural people by acting as a prime stage for buying and selling agricultural products. This study analyzes the existing scenario and also reveal the problems of the growth center. The study market meets a great demand of the people of the surrounding area. This helps to create a various opportunity for the residence and also makes a great change to the lifestyle of the residence. For these reasons, this study also focuses on potential of the growth center. But there are also some problems. If all these problems can solve systematically, then it will be more effective for the people. To enhance the drawbacks of existing growth center management, the study attempts to recommend some measurements and guidelines for solving the problems of the growth center.

Keywords: growth center, problems, potentials, measurement.

GJMBR-G Classification: JEL Code: ROO

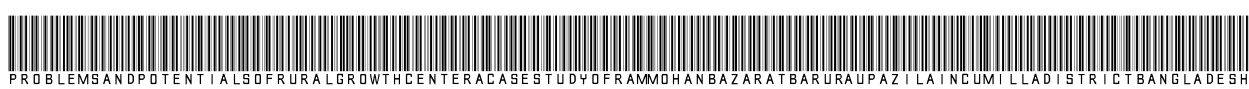

Strictly as per the compliance and regulations of:

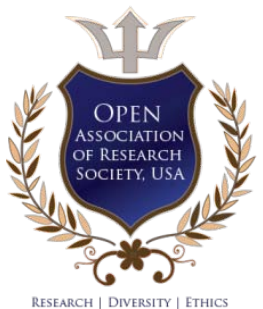

(C) 2020. Md. Ziaul Haq. This is a research/review paper, distributed under the terms of the Creative Commons AttributionNoncommercial 3.0 Unported License http://creativecommons.org/licenses/by-nc/3.0/), permitting all non-commercial use, distribution, and reproduction in any medium, provided the original work is properly cited. 


\section{Problems and Potentials of Rural Growth Center: A Case Study of Rammohan Bazar at Barura Upazila in Cumilla District, Bangladesh}

Md. Ziaul Haq

Abstract- Rural growth center can play a vital role in developing the economic condition of the rural people by acting as a prime stage for buying and selling agricultural products. This study analyzes the existing scenario and also reveal the problems of the growth center. The study market meets a great demand of the people of the surrounding area. This helps to create a various opportunity for the residence and also makes a great change to the lifestyle of the residence. For these reasons, this study also focuses on potential of the growth center. But there are also some problems. If all these problems can solve systematically, then it will be more effective for the people. To enhance the drawbacks of existing growth center management, the study attempts to recommend some measurements and guidelines for solving the problems of the growth center.

Keywords: growth center, problems, potentials, measurement.

\section{INTRODUCTION}

G rowth Center in the village can be compared with the Central Business District (CBD) of that arena. The growth center performs as a center of economic, social, and cultural activities in the rural areas. These are the venues where people exchange their ideas with their neighbors regarding improved methods of production and marketing and also serve as the center of recreation (Das and Mondal, 2010).

In Bangladesh, agriculture is the dominant sector of the economy. About $76.67 \%$ of the population lives in rural areas and agriculture is the main occupation of rural people (BBS, 2011). The growth centers, i.e., rural markets, hats, and bazaars are the only outlets for village products. Not only farmers but also many kinds of traders and craftsmen have been engaged in trading at these growth centers. At the same time, these growth centers are also the only channel through which urban industrial products, modern agricultural inputs and other daily needs of rural life enter into the village economy. Besides, these are the only centers in the rural area where off-farm employment can be generated by through improving different modes of transportation and establishing rural and cottage industries. Above all, people's meeting in the markets can help to motivate and grow awareness regarding

Author: Department of Urban and Regional Planning, Jahangirnagar University, Savar, Dhaka-1342, Bangladesh.

e-mail: mdziaulhaq800@gmail.com health care, education, population control, selfemployment, etc. can help to diffuse the knowledge and innovation. For these reasons, growth centerscan play an important role in the economic development of the rural areas and at the same time; contribute significantly towards local resource mobilization (Singha, 2006).

The growth centers is facing terrible constraints in their functioning in the rural areas, which directly affects on the rural economy. Most of the rural markets in Bangladesh have developed in an ad-hoc manner. These markets are likely to have minimal facilities and in dilapidated condition. Not only does this make trade difficult but also results in unnecessary spoilage and losses. As such, facilities, infrastructure, management and operations are haphazard and rarely meet the changing needs of market users. The operation and maintenance of the rural market are not entirely transparent. At the same time, it is apparent that market management is weak and unrepresentative. Markets generate significant revenue, but little finds its way back for expenditure on maintenance and further development.

There are about 17000 rural markets throughout Bangladesh are popularly known as hat or Bazar, and 2100 growth center spread over the country (Parna, 2011). Growth center, as well as rural market needs a pucca platform, interlink road, sheds, clean water, rain and waste management facilities etc but absence of these basic requirement in most of the rural markets and growth center of Bangladesh resulting in unhygienic and inefficient marketing condition which has straight outcome in the national economy. Improvement of the rural markets, therefore, assumes great importance in the overall development of the rural economy (Rashid, 2015).

Rammohan Bazaar's growth center is one of the biggest markets of Barura Upazila in the Cumilla District of Bangladesh. Most of the population was dependent on agriculture and fishery in the area, and this respect, the market can play a vital role in the development of economy of the locality, but the market is facing constraints in its way of functioning like a less effective market management committee, absence of proper utility and infrastructure facilities and rarely meet the changing needs of market users. 
No study has been conducted on the problems and potentials of the Rammohan Bazaar Growth Centre yet. On the other hand, the market management authority faces a big problem in developing the market systematically. In these circumstances, this article focuses on the existing scenarios, problems and potentials of this growth center. This article will help to reduce the constraints of functioning, utility services, infrastructure facilities and to meet the changing needs of market users that will help to improve the overall conditions of the market.

\section{il. Literature ReVieW}

In the earlier studies related to the growth center we found evidence of the problems, potentials, and some possible measurements to develop the growth center. Marocchino (2009) provides practical guidelines for improving agricultural retail markets in rural areas and analyses the strategic potential of upgrading as an significant component of rural development. Mondal \& Das (2010) focus on the growth center for the economic \& social development of rural Bangladesh. After building the growth center, the changes in social life along with the physical development of this area have been visible. In recent years the purchasing intensity of different sectors such as agriculture, fisheries, etc. input increased very fast. Thus, the numbers of buyers and sellers, trade volume and turnover in these markets have increased, which extends local development. But these rural markets are holds various problems, which are mostly connected with infrastructure. Growth centers with better infrastructure facilities are likely to play a wider role in the rural economy \& development. It has been seen that the provision of infrastructure in rural markets actually paves the way for employment generation and contributes to increasing number of traders and market turnover. Barua, Akter \& Jahan (2015) emphasized on Rural-urban linkage through growth centers in Bangladesh. In this paper, the existing condition of rural-urban linkage through growth centers has been studied. Based on the study, some recommendations have been proposed, which may increase the efficiency of the marketing system to improve the rural-urban linkage.

\section{ili. Data And Methodology}

The research study is conducted with a predesign methodology. Relevant and required data are collected both from primary and secondary sources.

Secondary data, including Growth center related information such as, the profile of the Market and functions of a market management committee and information on shops, etc. These data were collected from market management committee. It also includes the Annual Budget Report. Supporting information collected from Bangladesh Bureau of Statistics and
Bangladesh Economic Review. Information was also collected from several books, thesis papers, articles, journals, newspapers etc. and used the internet service to collect data.

Primary data were collected from January to February 2020. Primary data are collected by the following methods.

\section{$>$ Observation method}

This method implies collecting information by way of the investigator's observation, without interviewing the respondents (Kothari, 2004). This method was used to achieve the preliminary knowledge and make some basic concepts. This method is very helpful in achieving a clear idea about the existing conditions and problems of the market.

$>$ Data collection through questionnaire and visitors count survey

A survey questionnaire is prepared for collecting Information from the Sellers, Buyers and market authority to meet the required data to fulfill the study objectives. Questionnaires were developed, encompassing all the data in data list that need to be collected. A total of 200 interviews is conducted from Sellers and Buyers separately. A focus group interview was conducted from market committee. Visitors Count Survey has been developed for counting total number of visitors comes in the market in hat day and normal day.

\section{$>$ Photography}

Photography of a phenomenon can explain the present situation more preciously. Took photographs of different phenomena of growth center that helps to fulfill the research work. These photographs include shops conditions, solid waste storage facilities, waste collection, container, drainage, transportation, dumping site, etc.

The study was conducted through a qualitative case study design from constructivist paradigm, which implies that reality is constructed from the social world. Data were collected through purposive and snowball sampling. The report was presented through narrative, tabular and figure form and illustrative data extract to support arguments about the research questions and literature (Hossain, Ahmmed, \& Chowdhury, 2019).

\section{a) Case profile}

Rammohan Bazar at Barura Upazilla in Cumilla District has selected for the study after realized the different problems of the growth center. These problems hamper the socio-economic development of the locality.

Rammohan Bazaar is the biggest and most famous growth center in Barura Upazilla. It was established in the British period, and the area of the market is 6.86 acre. All kinds of vegetables, fish, rice and other commodities are supplied to the small markets from here. The location of the market is in important position. It is situated border side of Barura 
Upazila (figure 01). On the other side of the growth centre is Chandina Upazila. It serves the two Upazila easily. The market is easily accessible by both roads and waterways. In the north side of the growth center, is $7 \mathrm{~km}$ far from Dhaka- Chittagong highway.

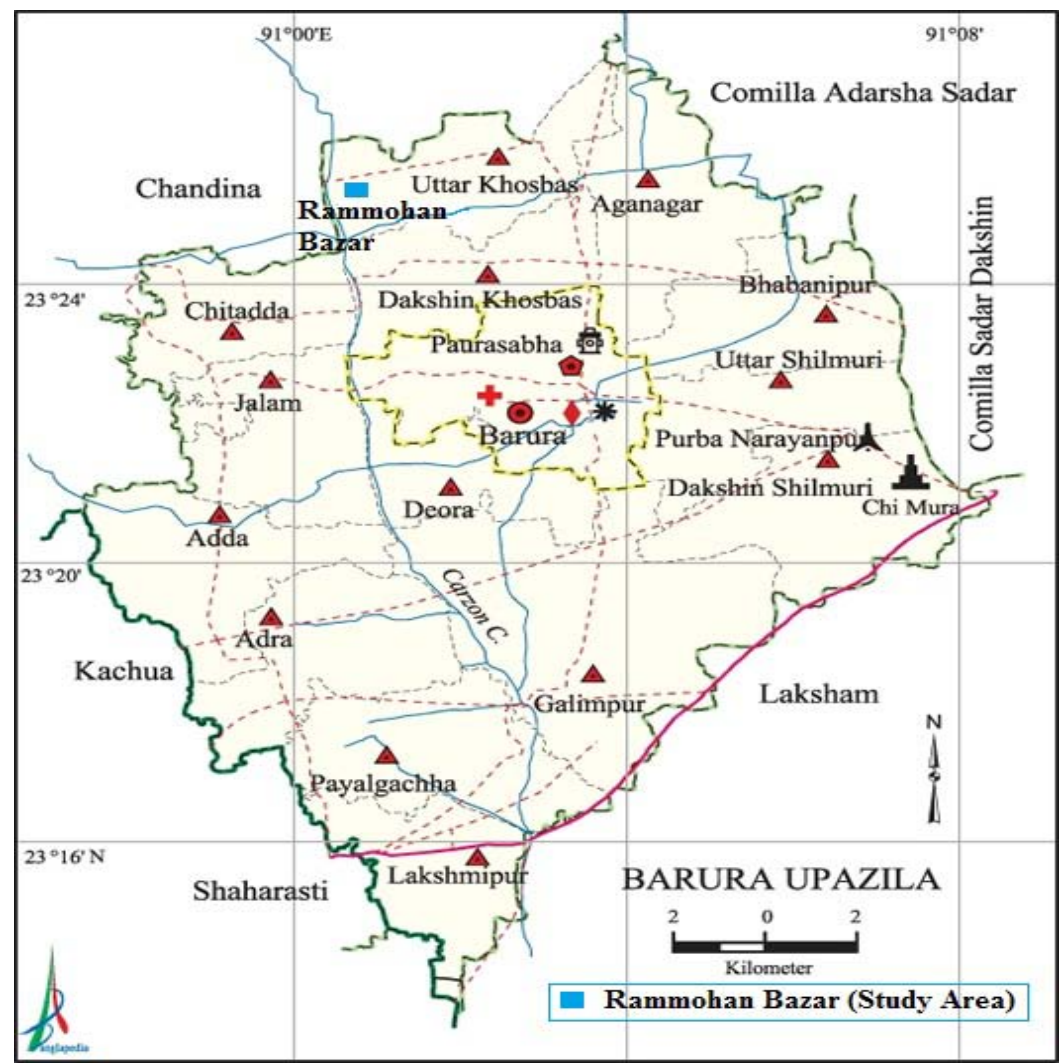

Source: Banglapedia and modified by author, 2020

Figure 1: Location map of the study area

An interlinked road (Dhaka- Chittagong Highway to growth center) is connected with the growth center. Visitors usually come here by road through nonmotorized and motorized vehicles. The backward linkage through waterway (Curzon canal) is only used for goods transportation but recently waterway is unsuitable for good transportation due to unplanned embankment and build of structure on the canal. In the market, there are both permanent and temporary shops. Interview from the market authority, it is found that permanent and temporary shops are 495 and 69 respectively and its serves the 21 villages in the surrounding of the Bazar. The catchment area of the bazaar is almost $7 \mathrm{~km}$ at the North, $6 \mathrm{~km}$ at the South, 7 $\mathrm{km}$ at the East and $7 \mathrm{~km}$ at the west.

Table 01 reveals that the total number of visitors both male and female in the market is 6784 person in hat days. The visitor during 05-06 pm is 1516 person which is $22.77 \%$ of male visitors. It is the highest intensity of visitors in one hour. The visitor who comes from the close proximity of the growth center is relaxed to make their visiting period. It also observed that a small number of female visitors come to the growth center.
Table 02 depictions that the total numbers of visitors in the market are 2304 person on a normal day. The highest visitor during 05-06 pm is 502 person. Visitors who come in the market in normal day, Most of the visitors lived in the close proximity of the market. A small number of visitors come in the market from far away in the normal day. A small number of female visitors also come to the market in normal day. The female visitors prefer the market visit in day. They went back to their house before the sunset for this reason female visitors usually not seen at night.

There are a different kinds of institutions are situated in this market. They are one primary school, one high school, two mosques, one temple, one youth centers, one clinic/health care center, three banks, one $\mathrm{NGO}$, one market committee office and one post office. 
Table 1: The entry of visitors in hat day

\begin{tabular}{|c|c|c|c|c|}
\hline \multirow{2}{*}{ Period } & \multicolumn{4}{|c|}{ Entry of visitors in hat day } \\
\cline { 2 - 5 } & $\begin{array}{c}\text { Number of } \\
\text { male visitors }\end{array}$ & $\begin{array}{c}\text { Percentage of } \\
\text { male visitors }\end{array}$ & $\begin{array}{c}\text { Number of } \\
\text { female visitors }\end{array}$ & $\begin{array}{c}\text { Percentage of } \\
\text { female visitors }\end{array}$ \\
\hline $07-08 \mathrm{am}$ & 82 & 1.23 & 0 & 0 \\
\hline $08-09 \mathrm{am}$ & 195 & 2.93 & 7 & 5.51 \\
\hline $09-10 \mathrm{am}$ & 275 & 4.13 & 13 & 10.23 \\
\hline $10-11 \mathrm{am}$ & 148 & 2.22 & 17 & 13.39 \\
\hline $11-12$ & 123 & 1.85 & 5 & 0 \\
\hline $12-01 \mathrm{pm}$ & 108 & 1.63 & 0 & 2.36 \\
\hline $01-02 \mathrm{pm}$ & 96 & 1.44 & 3 & 3.14 \\
\hline $02-03 \mathrm{pm}$ & 203 & 3.05 & 4 & 15.75 \\
\hline $03-04 \mathrm{pm}$ & 523 & 7.86 & 20 & 14.42 \\
\hline $04-05 \mathrm{pm}$ & 993 & 14.92 & 31 & 5.52 \\
\hline $05-06 \mathrm{pm}$ & 1516 & 22.77 & 18 & 1.57 \\
\hline $06-07 \mathrm{pm}$ & 1305 & 19.60 & 07 & 0 \\
\hline $07-08 \mathrm{pm}$ & 829 & 12.45 & 2 & 100 \\
\hline $08-09 \mathrm{pm}$ & 207 & 3.11 & 0 & 0 \\
\hline $09-10 \mathrm{pm}$ & 54 & 0.81 & 127 & \\
\hline Total & 6657 & 100 & & \\
\hline
\end{tabular}

Source: Field survey, 2020

Table 2: The Entry of visitors in normal day

\begin{tabular}{|c|c|c|c|c|}
\hline \multirow{2}{*}{ Period } & \multicolumn{4}{|c|}{ Entry of visitors in normal day } \\
\cline { 2 - 5 } & $\begin{array}{c}\text { Number of } \\
\text { male visitors }\end{array}$ & $\begin{array}{c}\text { Percentage of } \\
\text { male visitors }\end{array}$ & $\begin{array}{c}\text { Number of } \\
\text { female visitors }\end{array}$ & $\begin{array}{c}\text { Percentage of } \\
\text { female visitors }\end{array}$ \\
\hline $07-08 \mathrm{am}$ & 27 & 1.21 & 0 & 0 \\
\hline $08-09 \mathrm{am}$ & 61 & 2.74 & 2 & 2.5 \\
\hline $09-10 \mathrm{am}$ & 85 & 3.82 & 5 & 6.25 \\
\hline $10-11 \mathrm{am}$ & 74 & 3.33 & 9 & 11.25 \\
\hline $11-12 \mathrm{Noon}$ & 41 & 1.84 & 3 & 3.75 \\
\hline $12-01 \mathrm{pm}$ & 33 & 1.48 & 0 & 0 \\
\hline $01-02 \mathrm{pm}$ & 32 & 1.44 & 1 & 1.25 \\
\hline $02-03 \mathrm{pm}$ & 64 & 2.88 & 1 & 1.25 \\
\hline $03-04 \mathrm{pm}$ & 174 & 7.82 & 12 & 15 \\
\hline $04-05 \mathrm{pm}$ & 331 & 14.88 & 17 & 21.25 \\
\hline $05-06 \mathrm{pm}$ & 502 & 22.57 & 20 & 7.5 \\
\hline $06-07 \mathrm{pm}$ & 435 & 19.56 & 06 & 5 \\
\hline $07-08 \mathrm{pm}$ & 276 & 12.42 & 04 & 0 \\
\hline $08-09 \mathrm{pm}$ & 69 & 3.11 & 0 & 100 \\
\hline $09-10 \mathrm{pm}$ & 20 & 0.90 & 0 & \\
\hline Total & 2224 & 100 & 80 & \\
\hline
\end{tabular}

Source: Field survey, 2020

\section{Problems of the Growth Center}

Though the importance of growth center in rural area is immense but lack of concern of government these show limited performance than their actual potentialities.

a) Opinion about problems faced by sellers

Sellers of the market face various kinds of problems. In figure 02 shown 23 percent of respondents said that about the inadequate waste collection which is the main reason of creating negative impact of the market and 22 percent respondents said that about lack of maintenance system of the market. Only 6 percent of respondents said that politically biased ness in the time of shop renting or buying. 


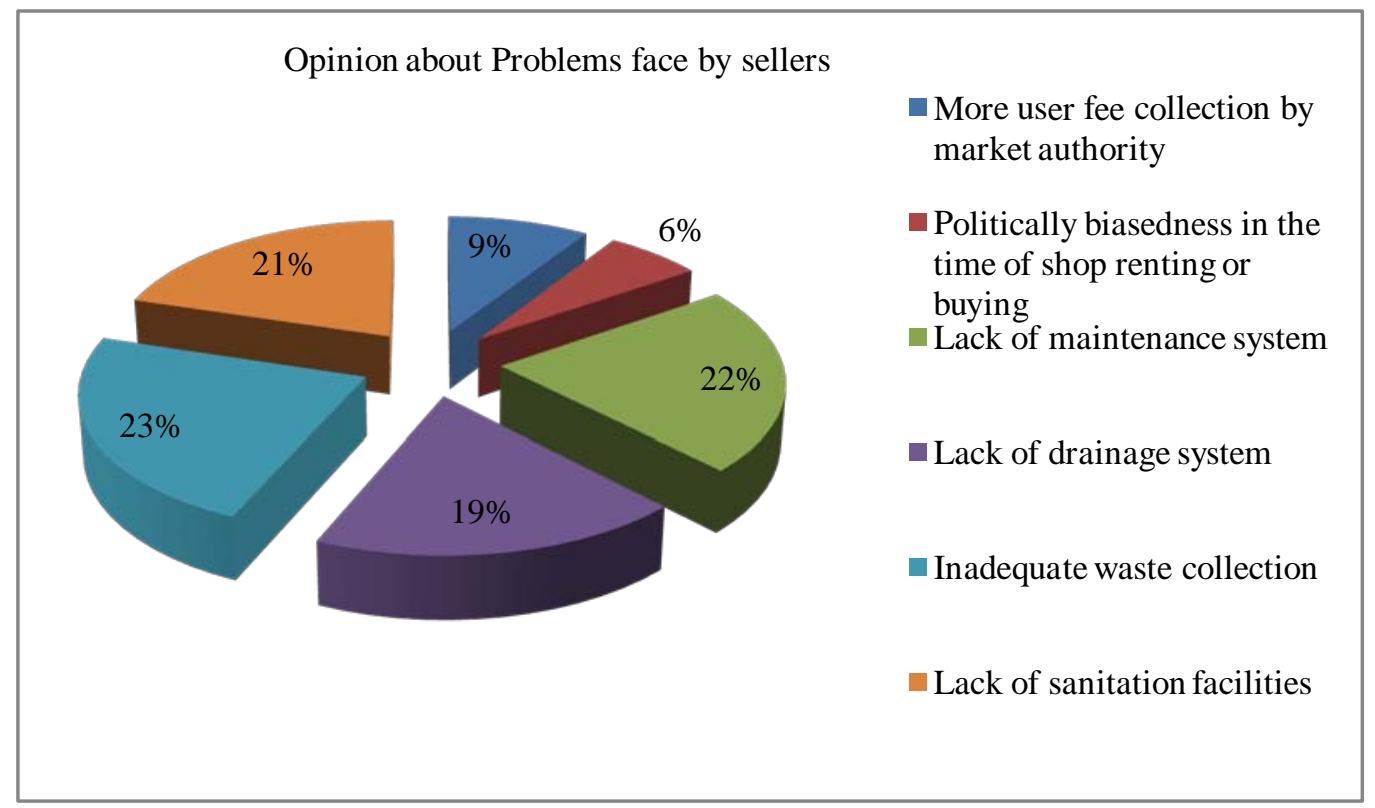

Source: Field Survey, 2020

Figure 2: Opinion about problems faced by sellers

b) Types of problems are faced by Buyer

Buyers are also facing a different kinds of problems. From the interview of buyers, it is found that 35 percent respondents said that lack of a vehicle to communicate with the market and 25 percent of respondents also mention high transport costs for traveling the market. In figure 03 shown only 4 percent of respondents said that lacks of products are available here for that reason they do not find their required product in the market.

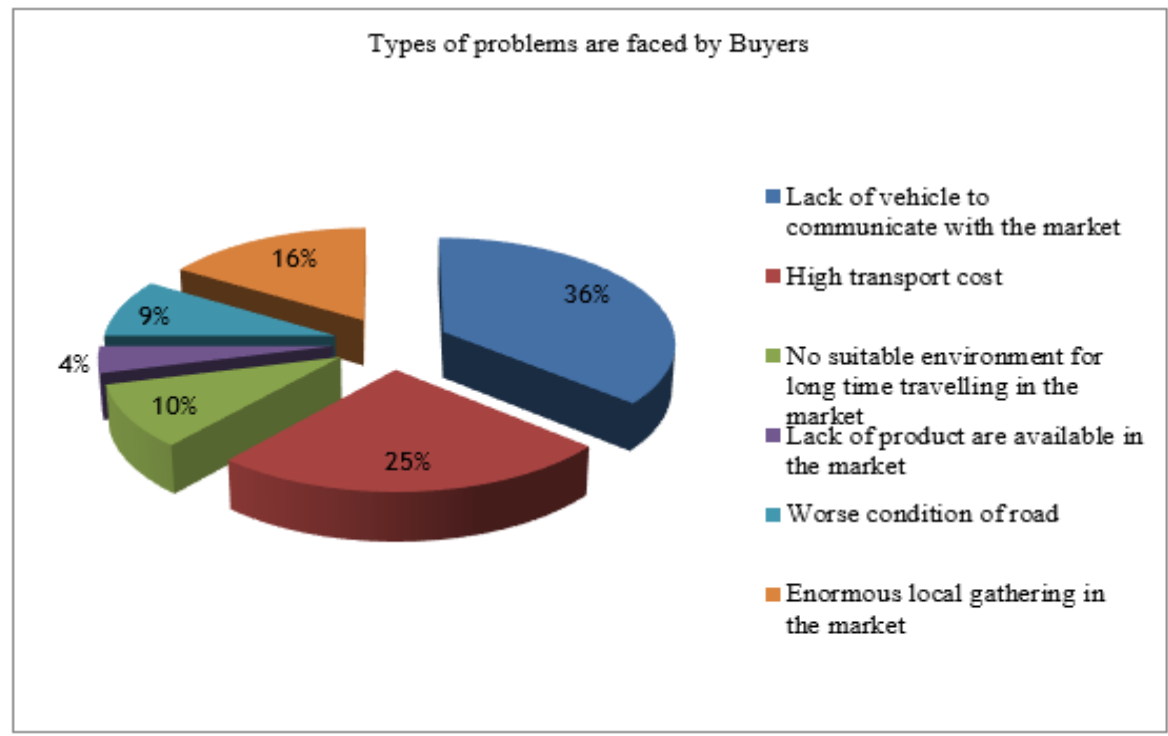

Source: Field sunvey, 2020

Figure 3: Types of problems are faced by Buyer

\section{c) Condition of road surface}

The road within the market is not wide enough and surface cracks were found here and there, which is the leading cause of accidents in this area. Some portion of the road surface became useless. During the rainy season, water logging is a common seen.

\section{d) Encroachment of road space}

Some open spaces of the market have encroached by the powerful local people, due to lack of adequate space, goods are assembled and transected on the road side; offers for sale by the grower and traders, which lead to congestion within the market area. 


\section{e) Loading and unloading facilities}

The study area has no specific space for loading and unloading goods. That is why operators always load or unload their goods into the market. This also creates congestion and damage to internal roads

\section{f) Waste Disposal System}

The waste disposal system of Rammohan Bazar is very poor to describe. Every day the whole market generates a huge amount of organic, inorganic and kitchen market waste but there is a lack of proper management options for these wastes. At the finishing of hat days the whole market is cleaned by the sweepers. But it is not regular and adequate. Besides, due to lack of dustbins solid wastes are disposed of here and there which create odor and unpleasant to look at.

\section{g) Sanitation condition}

Though there are two public toilets found but their condition is very bad. Servicing is not regular. As they are in deteriorating condition, people do not want to use them. The open areas for latrine's purpose. One latrine is situated beside the Curzon canal of the Rammohan Bazar, and other is situated inside the market. These are creating environmental pollution, odor and hamper the buyer and seller to movement in the market.

\section{h) Existing dumping sites of the market}

From the field survey, 2020 it is found that existing dumping sites are near to the water body and road sides. For this reason, these dumping sites are mainly liable to create water pollution, air pollution, odor, and visually not pleasant (Figure 04).

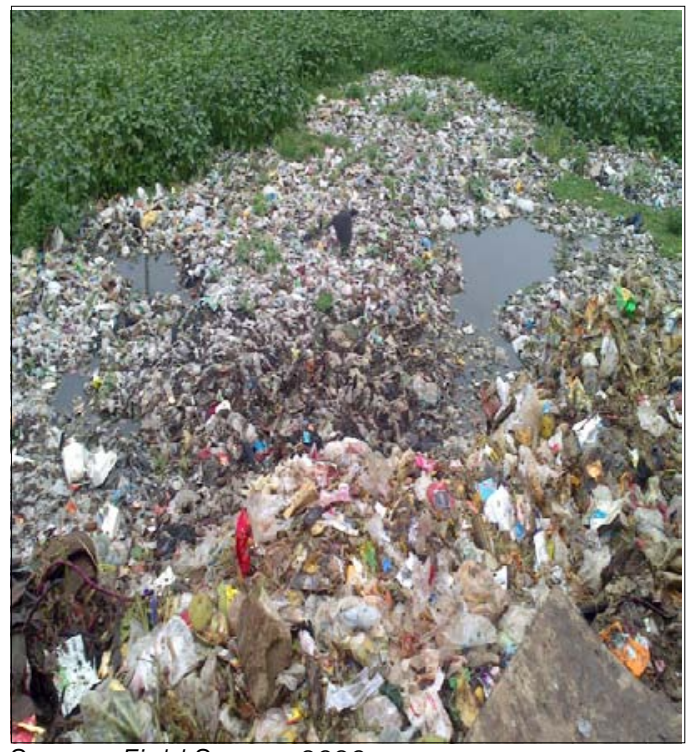

Source: Field Survey, 2020

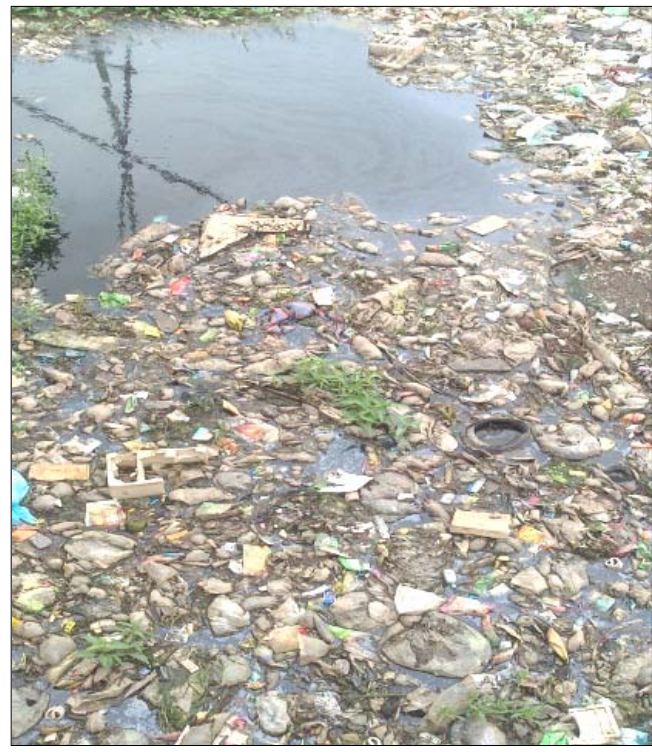

Figure 4: Existing dumping sites of the market

\section{i) Dredging of Curzon canal}

Rammohan Bazar is situated beside the Curzon canal. But the present time Curzon canal is unsuitable for boat or launch movement because of unplanned embankment is constructed in the Curzon canal. Irregular dragging also obstructs the movement of the boat.

j) Opinion about the satisfaction of existing facility provide by market authority

Rammohan Bazar Market Management Committee tries to provide sufficient facilities for the sellers. But sometimes the authority facing a financial and technical problem for these reason they does not provide sufficient facilities. From the field survey 2020, it is found that 45 percent of sellers are not satisfied with the facility provided by market management committee.

\section{Potentials of the Growth Centre}

There are a lot of potentials in the studied growth center. This growth center is strengthening the local economy.

\section{a) Positive impacts of the market}

Growth center is functioning in the grass root level of rural development and it acts as an economic hub of the rural areas. Without their presence economic activities of rural area will be stopped so they have high influential characteristics in the context of the rural economy. Every single growth center and the rural market is influence he rural economy by making a large amount of market revenue. 


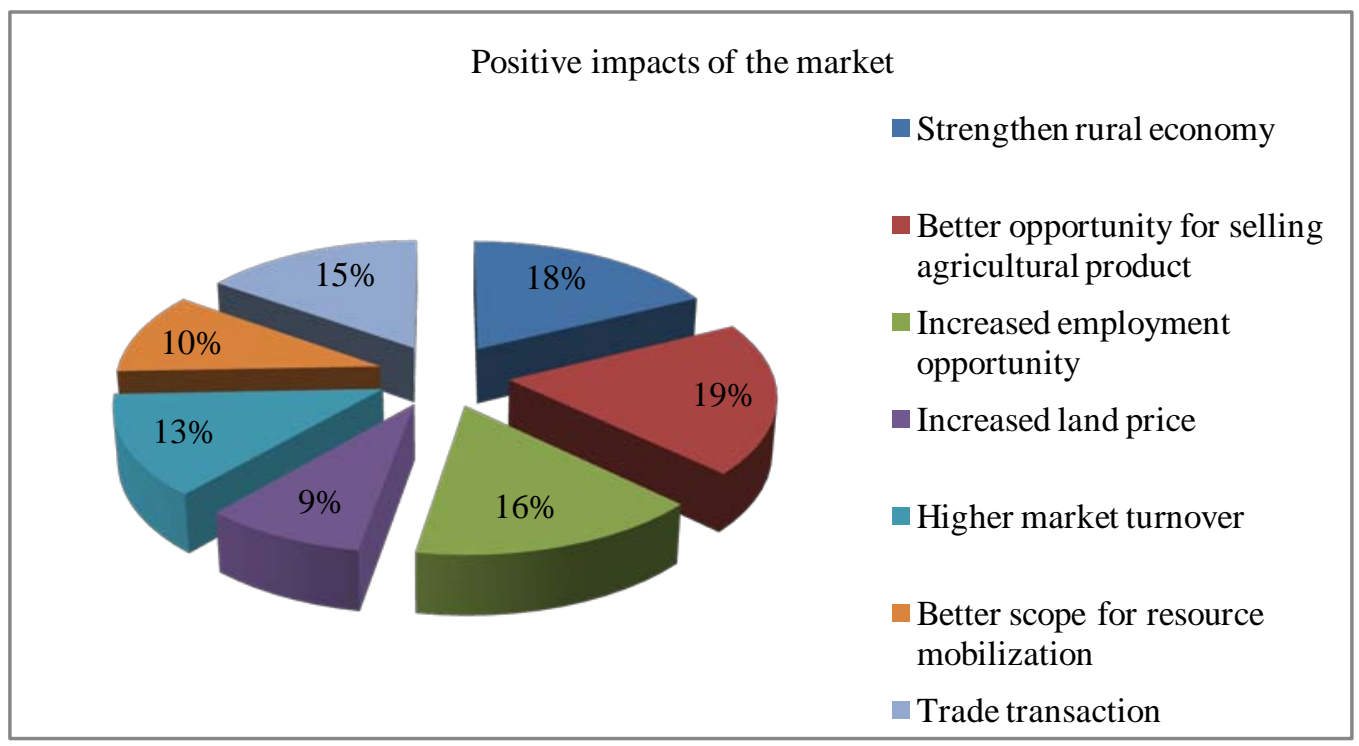

Source: Field survey, 2020

Figure 5: Positive impacts of the market

From the field survey, 2020, it is found that 19 percent of respondents said that the Rammohan Bazar growth center is a better opportunity for selling agricultural products and 18 percent of respondents said that this growth center contributes to strengthening the rural economy. About $16 \%$ of respondents said that this growth center is important source of employment generation. Only 15 percent of respondents said that this growth center contribute to trade transaction.

\section{b) Monetary transaction}

Monetary transactions is playing an important role in rural growth centers. The function of the growth center is a trade transaction. In the past, monetary transactions were very low. But day by this transaction is increasing. Table 03 shown the monetary transaction in the growth center.

Table 3: Monetary transaction in the growth center

\begin{tabular}{|c|c|c|}
\hline \multirow{2}{*}{ Type } & \multicolumn{2}{|c|}{ Monetary Transaction } \\
\cline { 2 - 3 } & 2006 (Year) & 2020 (Year) \\
\hline Hat day & $300000-500000 \mathrm{tk}$ & $10000000-15000000$ tk \\
\hline Non- hat day & $50,000-100000 \mathrm{tk}$ & $2500000-5000000$ tk \\
\hline
\end{tabular}

Source: Rammohan Bazar Management Committee, 2020

\section{c) Origin of employment and earnings}

The Growth center is not only a marketplace but also generates employment that improves the condition of the rural poor. From the interview of the market authority, in 2006, the number of shops was 366 and in 2020 the increase of shops continued and reached at 564 and every shop needs two workers for run the shop properly running. After fourteen years, there was an increase of 198 shops that means the growth center creating employment for more 396 people in 198 shops. To carry a market products or take in or take off visitors from villages or main road to market area local young people mainly involve they run their vehicles or get rent from others.

\section{d) Distance nexus land value of growth center}

Land values of the catchment area vary depending on the inherent quality of the land for agriculture, fisheries, livestock, etc. Land value also depends on the proximity to the growth center. Significant indirect influence is observed on cropland values through capitalization of income from commodity supply by growth center. Land values are closely tied to the income-generating capacity of the land. Production of rice, vegetables, serials, shrimp, livestock, miscellaneous trees, etc. influences on significant increase of land value that is closely linked with growth center (Das and Mondal, 2010). The land value of Rammohan bazar growth center service area was closely linked with production, service facility, transportation network etc. The average land value of the service area is shown in figure 6 in respect to proximity to the growth center 


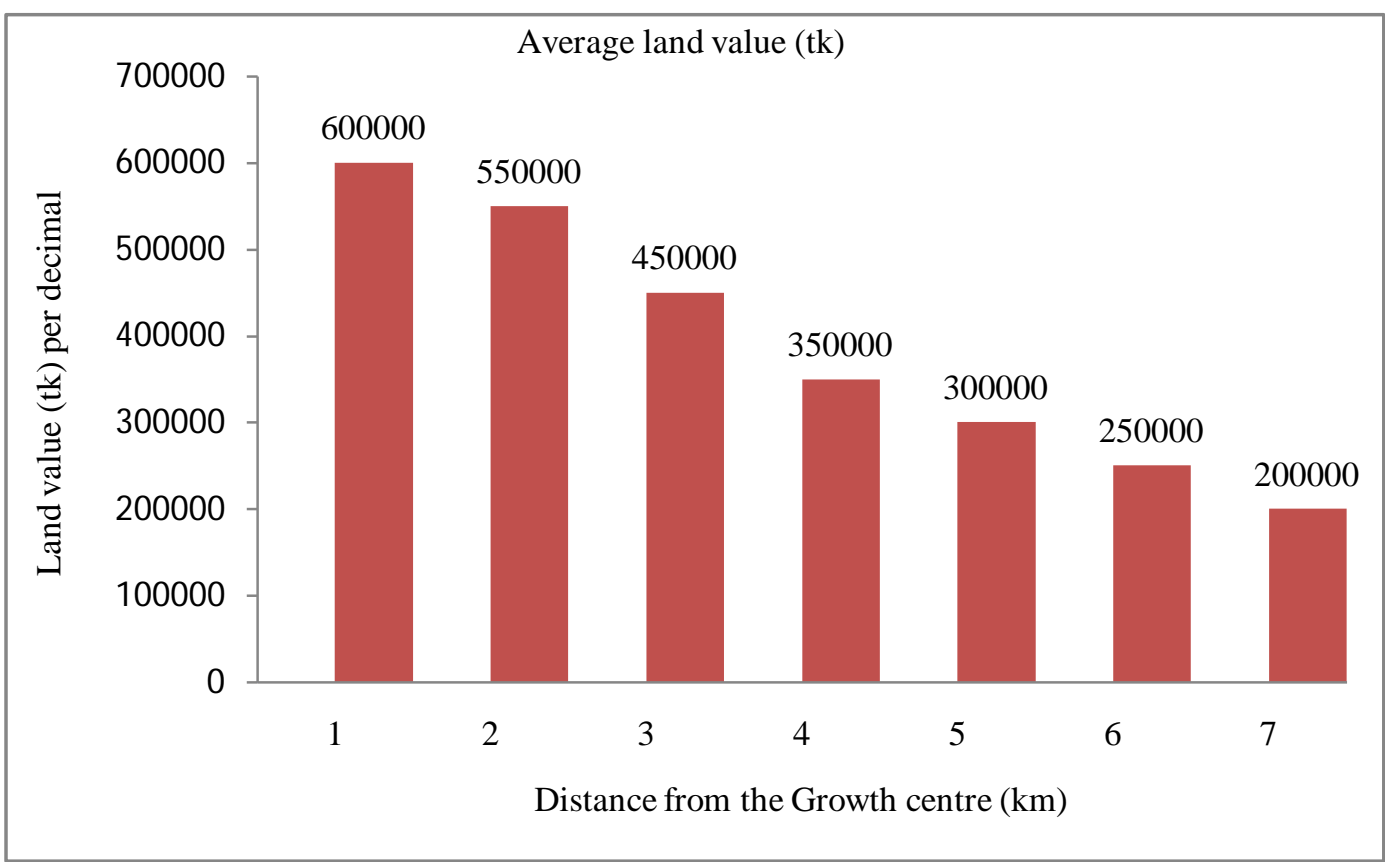

Source: Field survey, 2020

Figure 6: Distance from the growth center nexus land value

The land value decreased with the increase of distance from the growth center. The average land value was the highest within one kilometer as Tk.600000 per decimal, most of the services and facilities exist in the area and people were in good access to the growth center. Otherwise, due to lack of access to products market and other influencing services, the increasing distance decreased the land value. So it indicated that the high demand of the land of the adjacent areas of growth center resulted in social and economic development.

\section{e) Resource mobilization}

A Rural growth center is a powerful tool for domestic resource mobilization. The Growth center has very successfully mobilized locally available resources both cash and crops in the rural area. Couple with the effect of developing the growth center with the injection of investment has surfaced the growth center as model of enhancing rural economy. The Rammohan Bazar growth center is a great source of resource mobilization and the local people can trade their goods through the market.

\section{f) Growth center: a growing point for comprehensive} rural development

Rammohan Bazar growth center served visitors as a place not only for shopping/buying but also as a center for social, political, recreational activities. The visitors spend their time sharing their different ideas or views that helped for their social development and the political leaders/supporters used this place for their political purpose. The people of the community spend their time in the growth center for recreational purposes (Table 4).

Table 4: Purpose wise time spending in the growth center by visitors

\begin{tabular}{|c|c|c|c|c|c|c|c|c|}
\hline \multirow{2}{*}{ Purpose of visit } & \multicolumn{6}{|c|}{ Time spending each visit (Hour) } & \multirow{2}{*}{ Total } & \multirow{2}{*}{ Percentage } \\
\hline & $0-1$ & $1-2$ & $2-3$ & $3-4$ & $4-5$ & $>5$ & & \\
\hline Buying & 31 & 53 & 47 & 13 & 7 & 5 & 156 & 78 \\
\hline Political & & & 3 & 2 & 5 & 3 & 13 & 6.5 \\
\hline Social & 1 & 4 & 6 & 1 & 2 & & 14 & 7 \\
\hline Recreational & 2 & 7 & 1 & & & & 10 & 5 \\
\hline $\begin{array}{c}\text { Medical } \\
\text { treatment }\end{array}$ & & 1 & 4 & 2 & & & 7 & 3.5 \\
\hline Total & 34 & 65 & 61 & 18 & 14 & 8 & 200 & 100 \\
\hline Percentage & 17 & 32.5 & 30.5 & 9 & 7 & 4 & 100 & \\
\hline
\end{tabular}

Source: Field survey, 2020 
Table 4 illustrates the visitor's choice for coming and spending time in the growth center. The highest 78 percent people visit the growth center for buying purposes and the second-highest (7 percent) visitors visit for social purposes and respectively 6.5 percent for political and 5 percent for recreational purposes. On the other hand, most of the visitors stayed more than 1 to 2 hours in the growth center for different purposes and 30.5 percent people spend 2 to 3 hours. Only 4 percent visitors spend more than five hours, who were staying for buying and political purposes. Finally, it could be said that the growth center is not only playing a role for selling and buying, but also it had effects in the social, political, and recreational arena for the rural people.

\section{g) Recreational facilities}

The growth center and recreation facility hosts a multitude of services for rural people and plays both an active and passive role in the quality of life for the service area inhabitants. The market management committee operates and maintains numerous recreational facilities. The facilities include playgrounds, meeting rooms, boats, canal side, and pond. These facilities bring persons with diverse backgrounds together to enjoy special events, relax, and strengthen community relations. The growth center was also a roaming, gossiping place in the evening of the day of the catchments area people likely who were live in the inner service area. The peoples were gathering on the side of the canal for fishing. All ponds were consolidated under one aquatics unit to form a more efficient and effective aquatics organization and also act as a swimming pool of rural people (Das and Mondal, 2010).

\section{h) Services and Facilities}

Rammohan Bazar growth center provides the services/facilities for the service area population. This center also influences the alignments of roads, rural small hat/bazaar, social institutions, educational and recreational facilities within the catchment area. Table 05illustrations the social services within or outside of the growth center. Table 05 states that social, administrative, economic and commercial services network are inter-related with the Rammohan Bazar growth center. The important features are that the most needed facilities are developed within this growth center. Some services are within $10 \mathrm{~km}$ from the growth center, such as the general store and police camp. Finally, the social service institution developed in relation to the growth center helped to boost up the morale of the local people. On the other hand, the volume of services of the social institution decreased outside of the catchment area. Table 05 shows that most of the service institutions were found within the growth center.

Table 5: Distance of the nearest facilities from growth center

\begin{tabular}{|c|c|}
\hline \multicolumn{1}{|c|}{ Social and administrative services } \\
\hline Pypes of facilities Distance & In the growth center \\
\hline High School & In the growth center \\
\hline Madrasha & $2 \mathrm{~km}$ \\
\hline College & $4 \mathrm{~km}$ \\
\hline Park & 1 km \\
\hline Playground & In the growth center \\
\hline Community center & In the growth center \\
\hline Club & In the growth center \\
\hline Mosque & In the growth center \\
\hline Youth centers \& libraries & In the growth center \\
\hline Police camp & $5 \mathrm{~km}$ \\
\hline Clinic/Health care center & In the growth center \\
\hline Economic and commercial services \\
\hline Bank/NGO & In the growth center \\
\hline Bus/ other vehicle stand & In the growth center \\
\hline Nearest hat/bazaar & $8 \mathrm{~km}$ \\
\hline General store & $10 \mathrm{~km}$ \\
\hline
\end{tabular}

Source: Field survey, 2020

\section{Recommendations}

The study market meets a great demand of the people of the surrounding area. This helps to create employment opportunities to the residence and also makes a great change to the lifestyle of the residence. But there have also some problems. If all these problems can solve systematically then it will be more effective for the people. To enhance the drawbacks of existing growth center management, the following recommendations should be considered.

a) Improving the existing service facility of the market

There are many problems that are contains in the Rammohan Bazar. Proper drainage of a storm and 
waste water is very essential to ensure a working environment in a market. Logging of water makes the area muddy and unhygienic, which creates inconvenience in carrying out market activities. In figure 07, it is found that 31 percent of respondents said that the drainage facility should be increased because the portions of the market become inundated during the rainy season. The entire road of the market become muddy and sleepy, due to the absence of proper drainage system. To solve this inconvenience, extension and improvement of active drainage facilities in the entire area is needed. The drainage system that is blocked with waste will be cleared to flow the water. About 29 percent of respondents said that improving the maintenance system because the maintenance system of the market is not good. The market authority is not enough concern for giving the requirement of buyers and sellers. A huge number of people come to the market regularly. Generally in the hat day gathering of people becomes more. It is urgently needed to establish 5 public toilets in the market area. About 27 percent of respondents said that a sewerage facilities should be developed. Though there are two toilets found but their condition is very bad. Servicing is not regular. As they are in deteriorating condition, people do not want to use them. 21 percent of respondents said that sanitations facility should be developed and maintenance of the existing facility. Though there is enough number of tube wells inside and near the market area but these are not sufficient to serve the whole market area during hat day. The scarcity of water becomes a major problem for the traders. Rammohan Bazar management authority said that 5 tube wells are needed to install in the market to reduce the water crisis. The surrounding condition of the tube wells should be clear regularly. Proper parking space in the market is needed to avoid congestion and to safely reach the goods into the shop. For the lacking of space, it becomes tough for the buyer to move the market easily. The study area has no specific space of loading and unloading goods. Goods are gathered beside the road. This creates congestion and damage to internal roads. For this reason, about 17 percent of respondents said that available space for loading and unloading goods should be provided. There is no storage facility in the market area. But storage facility is needed to store the product. It also protects the products from rotten. There is no facility to preserve nondurable products. 13 percent respondents said that storage facilities, such as warehouses should be established in the market for the preservation of products. In figure 07 depicts the respondent's opinion on improving the existing service facility of the market.

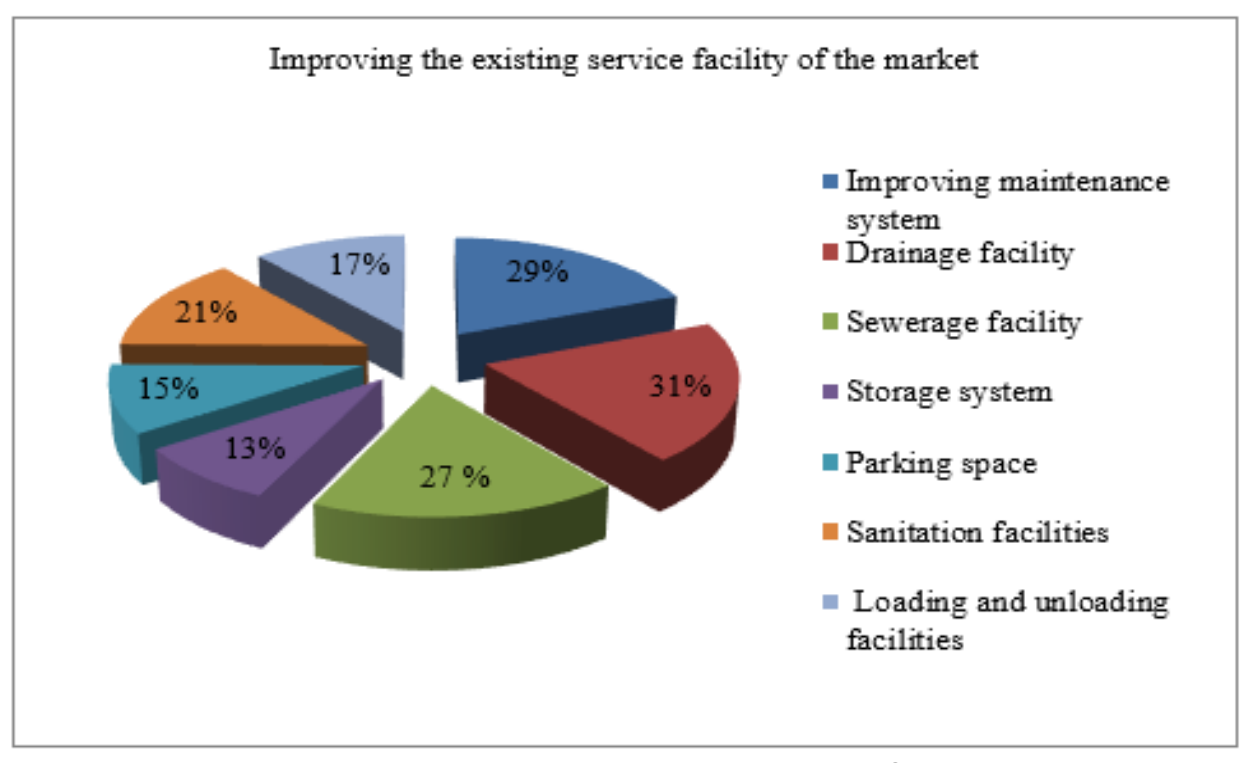

Source: Field survey, 2020

Figure 7: Improving the existing service facility of the market

b) Provide better communication facilities

Communication and transportation is the prerequisite for any development activity. The surface of the road of the market area creates problems for the movement of the people in the rainy season, it becomes muddy. The road surface should be well paved and the maintenance should be monitored and checked for better use.

\section{c) Providing recreational facilities}

The growth center and recreation facility hosts a multitude of services for rural people and plays both an active and passive role in the quality of life for the service area inhabitants. The market management committee can operate and maintain numerous recreational facilities. The Rammohan Bazar market authority should be provided of sitting arrangements for 
authority should be provided of sitting arrangements for gossiping or gathering of people beside the Curzon canal.

\section{d) Increasing environmental awareness}

Peoples of the market come from different places. People should be encouraged to use the proposed toilet, dustbin, etc. It can be effective with the help of a loud, pestering, milking, training, workshop for growing awareness of the user of the market.

\section{e) Provision of shed}

There should have sufficient permanent and temporary provision of sheds for fish and vegetables.

\section{f) Reducing congestion}

The market management authority takes some measurements to reduce the congestion during hat day. Proper sitting arrangements for temporary shops reduce traffic congestion. Regular monitoring is needed to reduce the congestion, which is created by the local vehicle.

\section{g) Protecting illegal encroachment}

The illegal encroachment of the market area should be legally protected. The market management committee and the Union Paris had can play a vital role here. Thus the extension of the market can be possible.

\section{h) Provide security}

The security system is an important tool for the development of the market. In the record of Bazaar committee, there are seven security guards but it is not enough for the market. According to the market management authority, extra 10 security guards should be needed for effective security system for the growth center. The security guard also should be well trained.

\section{i) Adequate electricity supply}

For the inadequate electricity supply, it becomes tough to continue the business in the evening period. From the evening period market generally open only for 3-4 hours. If the Rural electrification board becomes aware to supply electricity properly in that period then it will be very beneficial for the trader and buyer.

\section{j) Dredging of Curzon canal}

Rammohan Bazar is situated beside the Curzon canal. But the present time Curzon canal is unsuitable for boat or launch movement because of unplanned embankment constructed in the Curzon canal. Irregular dredging also obstructs the movement of boat. If the Curzon canal is suitable for the boat movement it is helpful for goods movement that will reduce the transport cost. So market authorities needs to take proper steps for dragging of Curzon canal including with government officials.

\section{k) The systematic arrangement of electric wire in the} market

The arrangement of electric wire in the Rammohan growth center is the very low height from the surface, which creates problems for a driver to move their transport particularly for the truck and also for the movers moving into the market area. Sometimes electric wire has become cut off because of the movement of a truck in the market area. The electric wire should be replaced height distance from the road surface so that trucks and visitors move the market easily.

\section{I) Reducing traffic accident}

This growth has been originated both side of 'Rammohan to Chandina' road where all type of transportation such as cycle, bus can move easily. But the growth center has no special arrangement to ensure user's safety. For this reason, a separate lane for the motorized and non-motorized vehicles, available parking space and specific stoppage location for motorized and non-motorized vehicle should be provided in the market. The temporary shops should be prevented from beside the main road of the market. These will be reduced the traffic accident in the market.

\section{m) Providing adequate space for temporary shops}

In the Rammohan market area, temporary traders have to sit on the road. So this internal road totally occupied by them and visitors cannot move easily. Temporary shops should be replaced beside the bank and provide adequate space for temporary shops.

\section{n) Solving financial problems for market maintenance and operation}

Rammohan Bazar authority will face a financial crisis in the time of market maintenance and operation. From the interview it is found that 172 respondents are willing to pay more money for providing better facilities if the Rammohan Bazar authority improves the existing service quality, they will pay more fees. So, The Rammohan Bazar authority needs to take many initiatives for service quality improvement and understand the respondents that ab sufficient amount will be needed for market maintenance and operation. Finally, it will generate more revenue.

\section{o) Providing lighting facilities}

Provide the proper lighting facilities to the growth center, which will help the rural people in the nighttime and give them security and safety.

\section{p) Suggestion to improve market waste management}

Indiscrimination and way-ward disposal of wastes in and around and it deteriorates the working environment of the market. Providing waste disposal provision at proximity of the market and ensuring regular cleaning of these provisions. For alleviating this situation, respondents suggest different options for 
effective market waste management. In figure 08, about 29 percent of respondents said that adequate numbers of dustbin or container should be provided for waste disposal. About 29 percent of respondents said that an appropriate location should be identifying for waste disposal. 15 percent of respondents mansion about the segregated collection of waste and only 8 percent respondents said that enhancing composting, recycling reuse facilities.

\section{q) Strong configuration of a market committee}

A Strong configuration of the market committee is very essential to operate and manage the market. To make a responsible and effective market committee, the following structure of the committee can be useful.
The market committee should comprise Thana Nirbahi Officer, Thana Engineer, Union Chairman, two local elites, Teacher of School/ college and two government officers.

Responsibility of the market committee could be:

- Preparation of Market development plan and implementation.

- Toll collection, supervision and control.

- Maintenance of law and order.

- Hat maintenance.

- Land use control.

- Review meeting.

- Informing the district commission regarding the management of the market.

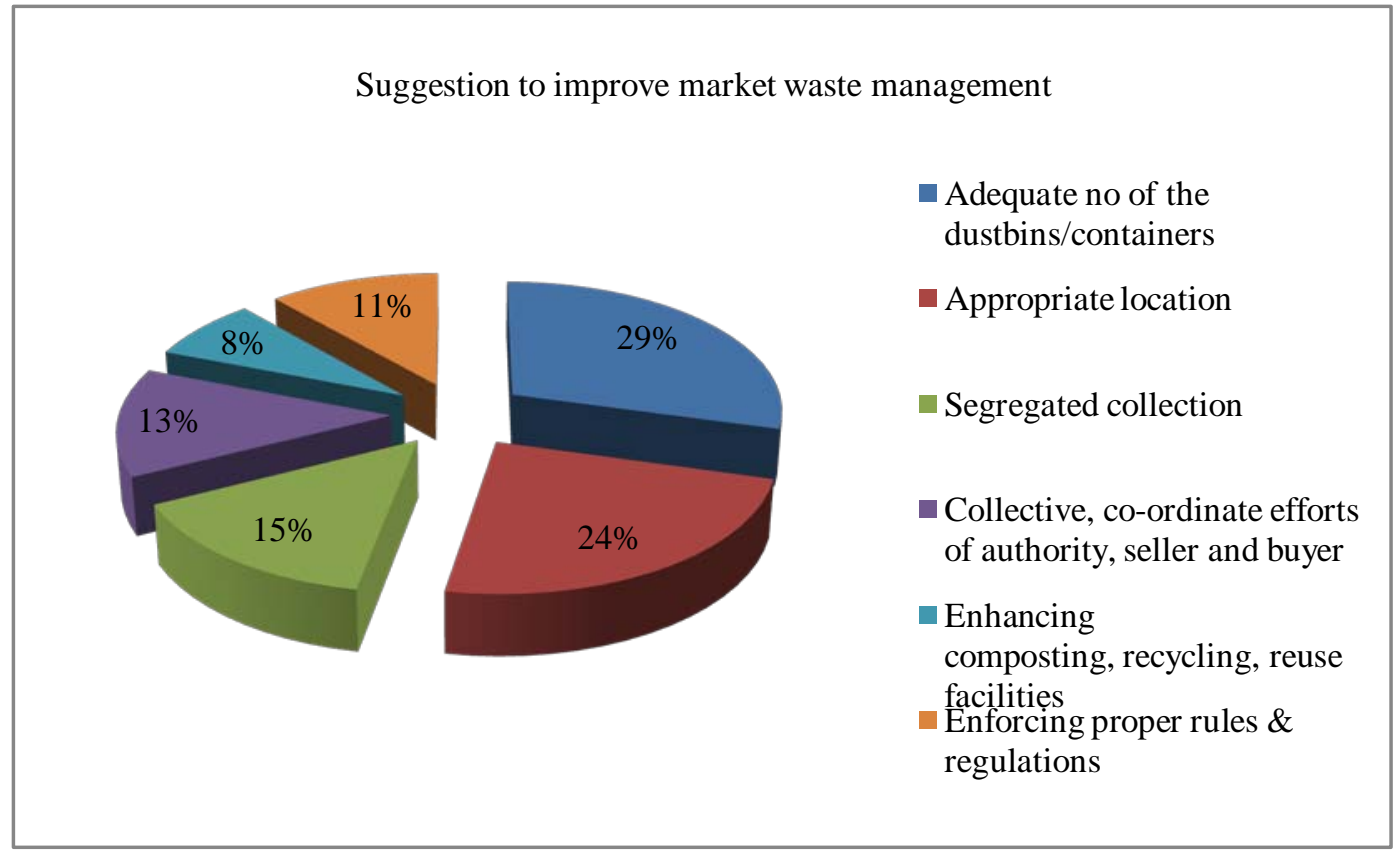

Source: Field survey, 2020

Figure 8: Suggestion to improve market waste management

\section{Vil. Conclusion}

Rural growth center plays a vital role in the socio-economic development of the rural area in Bangladesh. The provision of infrastructure facilities creates a favorable environment for economic uplift. The infrastructure element of the growth center, which can be termed as nerve center of rural economy. It has been seen that the provision of rural markets paves the way for employment generation and contributes to the increasing number of traders and customers, market lease rate and market turnover. All this has a significant role in the rural economy. This study focuses on the problems of existing conditions of growth center and potentials of the rural development by the improvement of the market conditions. Furthermore, the study will attempt to recommend some long-term measures and guidelines for solving the identified problems of the market.

The growth centers must be integrated with rural development policies by promoting agroprocessing industries, large investment from local or outer of its vicinity, provided necessary facilities and services to smooth its, function. Government has to play a significant role in the improvement of market facilities for better comfort. It is hoped that authority would realize the vital role of the markets in the society and at the same time; it should take necessary steps for the improvement of the market to enhance the rural economy as well as the national economy.

\section{Declaration of Conflicting Interests}

The authors declared no potential conflicts of interest with respect to the research, authorship and/or publication of this article. 
Funding

The authors received no financial support for the research, authorship and/or publication of this article.

\section{References Références Referencias}

1. Banglapedia (2020). Retrieved August 4, 2020 from http://en.banglapedia.org/index.php?title=Barura_U pazila.

2. Barua, U., Akter, R, and Jahan, S. (2015). RuralUrban Linkage through Growth Centers in Bangladesh.

3. Bangladesh Research Publications Journal, 10(4): 314-320. Retrieve from http://www.bdresearchpubli cations.com/admin/journal/upload/1410043/141004 3.pdf

4. BBS. (2011). Statistical year book of Bangladesh. Dhaka: Bangladesh Bureau of Statistics, Ministry of Planning, Government of Bangladesh.

5. Das, K., \& Mondal, B. K., (2010). Role of Growth Center: A Rural Development Perspective. Journal of Bangladesh Institute of Planners, 3,129-141. doi: ISSN 2075-9363

6. Kothari, C.R. (2004). Research Methodology (2 ${ }^{\text {nd }}$ ed.). New Delhi: New Age International (P) Ltd.

7. Marocchino, C. (2009). A guide to upgrading rural agricultural retail markets. Food and Agriculture Organization of the United Nations: Rome.

8. Parna, S. N., (2011). Role of growth centre and rural market in rural development of Bangladesh: a case study on Babugonj Upazila of Barisal district (Unpublished MURP thesis), Department of Urban and Regional Planning, Jahangirn agar University, Savar, Dhaka.

9. Rashid, S. (2015). Socio-Economic Impacts of Growth Centers on Rural Economy: A Case Study on

10. Kalampur Bazar of Dhamrai Upazila. (Unpublished MURP thesis), Department of Urban and Regional Planning, Jahangirn agar University, Savar, Dhaka.

11. Singha, K. B (2006). Planning Growth Center for Hinterland Area Development: A Case Study on Adampur.

12. Bazaar. Unpublished BURP Thesis, Department of Urban and Regional Planning, Jahangirnagar University: Savar, Dhaka.

13. Hossain, M. I., Ahmmed, F \& Chowdhury, M. S., (2019). Neoliberal Governmentality, Public Microfinance and Poverty in Bangladesh: Who are the Actual Beneficiaries? International Journal of Rural Management, 15(1) 23-48, 2019. Doi: 10.117 7/0973005218817657 